\title{
Two pediatric cases of pine nut allergy proved by oral food challenge
}

\author{
J Ponsaille ${ }^{1}$, T Bourrier ${ }^{2^{*}}$ \\ From Food Allergy and Anaphylaxis Meeting (FAAM 2013) \\ Nice, France. 7-9 February 2013
}

\section{Background}

Allergy to pine nuts is uncommon. Cases are reported in the literature but an oral challenge is rarely described especially in children.

\section{Methods}

We report the observations of two boys of age 5 and 11 formerly diagnosed with common food allergens. A secondary sensitization to pine nuts appears in skin prick tests using a commercial extract (Stallergènes ${ }^{\mathbb{B}}$, Antony, France). Specific serum IgE test (CAP-FEIA f253 Phadia ${ }^{\mathbb{B}}$ ) were performed. Because it was impossible to precise the consumption of pine nuts (anamnesis not informative enough), an oral food challenge was performed confirming.

\section{Results}

Skin prick tests were positive ( 8 and $20 \mathrm{~mm}$ respectively). Specific IgE tests were positive $(4.54 \mathrm{kU} / \mathrm{l}$ and $1.75 \mathrm{kU} / \mathrm{l}$ respectively). In both cases, oral food challenge confirm the allergy to pine nuts (eliciting dose $1000 \mathrm{mg}$ and $500 \mathrm{mg}$ respectively). Allergic reaction was controlled by medical team without anaphylaxis ; although such reaction is described in the literature with pine nuts. However, as reported in the literature, our patients had other food sensitizations. Indeed, cross reactivity is reported for food allergens (almond, peanuts and nuts in general) and also for respiratory allergens (pine pollen and Artemisia).

Exploration of pine nuts allergy should be careful because of a risk of anaphylaxis with native extracts for prick tests: therefore, commercial extracts should be used first.

2Pediatric Pneumology and Allergy Department, GCS Hôpitaux Pédiatriques de Nice CHU Lenval, Nice, France

Full list of author information is available at the end of the article

\section{Conclusion}

Pine nut is an increasing allergen because of its wide availability and because it is often hidden. The diagnosis is based on skin prick tests and specific serum IgE test when linked to a suggestive history. Oral challenge may be necessary to prove the allergy, especially to an unnecessary diet (i.e. exclusion of pine nuts).

\section{Disclosure of interest}

None declared.

\section{Author details}

${ }^{1}$ Private practice. ${ }^{2}$ Pediatric Pneumology and Allergy Department, GCS Hôpitaux Pédiatriques de Nice CHU Lenval, Nice, France.

Published: 25 July 2013

doi:10.1186/2045-7022-3-S3-P154

Cite this article as: Ponsaille and Bourrier: Two pediatric cases of pine nut allergy proved by oral food challenge. Clinical and Translational Allergy 2013 3(Suppl 3):P154.

Submit your next manuscript to BioMed Central and take full advantage of:

- Convenient online submission

- Thorough peer review

- No space constraints or color figure charges

- Immediate publication on acceptance

- Inclusion in PubMed, CAS, Scopus and Google Scholar

- Research which is freely available for redistribution 